14 - ORIGINAL ARTICLE

Investigative Surgery

\title{
Comparison between actual and predicted postoperative stair-climbing test, walk test and spirometric values in patients undergoing lung resection ${ }^{1}$
}

\author{
Comparação dos testes de escada, caminhada e espirometria preditos com os obtidos no \\ pós-operatório de ressecções pulmonares
}

\begin{abstract}
Marcos Vinícius Cataneo Pancieri', Daniele Cristina Cataneo ${ }^{\text {II }}$, Jair Cortez Montovani ${ }^{I I I}$, Antonio José Maria Cataneo ${ }^{\mathrm{IV}}$
${ }^{\text {I }}$ Fellow Master degree of Surgery, UNESP, Botucatu-SP, Brazil.

${ }^{\text {II }} \mathrm{PhD}$, Assistant Professor, Thoracic Surgery Division, Department of Surgery, Botucatu School of Medicine, UNESP, Botucatu-SP, Brazil.

${ }^{\text {III }} \mathrm{PhD}$, Associate Professor, Department of Otorrinolaryngology, Botucatu School of Medicine, UNESP, Botucatu-SP, Brazil.

${ }^{\text {IV }}$ Chairman Full Professor, Thoracic Surgery Division, Department of Surgery, Botucatu School of Medicine, UNESP, Botucatu-SP, Brazil.
\end{abstract}

\begin{abstract}
Purpose: To assess whether the tests - Forced Expiratory Volume at one second $\left(\mathrm{FEV}_{1}\right), 6$-minute walk test (6MWT) and stair-climbing test (SCT) showed proportional changes after the resection of functioning lung. Methods: Candidates for pulmonary resection were included. Spirometry, 6MWT and SCT were performed preoperatively (pre) and at least 3 months after surgery (pos). SCT was performed on a staircase with a total ascent height of $12.16 \mathrm{~m}$. The time taken to climb the total height the fastest possible was defined as stair-climbing time ( $\mathrm{SCt}$ ). Number of functioning segments lost, was used to calculated predicted postoperative (ppo) tests values. Pre, ppo and pos values for each test were compared. Data were analyzed by repeated-measure ANOVA with significance level set at $5 \%$. Results: A total of 40 patients were enrolled. Pulmonary resection results ranged from gain of 2 functioning segments to loss of 9 . Pre, ppo and pos values were the following: $\operatorname{preFEV}_{1}=2.6 \pm 0.8 \mathrm{~L}$, ppo $\mathrm{FEV}_{1}=2.3 \pm 0.8 \mathrm{~L}$, and pos $\mathrm{FEV}_{1}=2.3 \pm 0.8 \mathrm{~L}$, (pre $\mathrm{FEV}$, ppo $\left.\mathrm{FEV}_{1}=\operatorname{pos} \mathrm{FEV}_{1}\right) ;$ pre6MWT $=604 \pm 63 \mathrm{~m}$, ppo6MWT $=529 \pm 103 \mathrm{~m}, \operatorname{pos} 6 \mathrm{MWT}=599 \pm 74 \mathrm{~m}($ pre $6 \mathrm{MWT}=\operatorname{pos} 6 \mathrm{MWT}>\operatorname{ppo} 6 \mathrm{MWT}) ;$ $\operatorname{preSCt}=32.9 \pm 7.6 \mathrm{~s}, \operatorname{ppoSCt}=37.8 \pm 12.1 \mathrm{~s}, \operatorname{posSCt}=33.7 \pm 8.5 \mathrm{~s}(\mathrm{preSCt}=\operatorname{posSCt}<\mathrm{ppoSCt})$. Conclusion: In our group of patients, pulmonary resection led to loss of lung function measured by spirometry, but not to exercise capacity measured by stair-climbing and walk tests.
\end{abstract}

Key words: Respiratory Function Tests. Heart Function Tests. Spirometry.

\section{RESUMO}

Objetivo: Verificar se os testes: Volume Expiratório Forçado no $1^{\circ}$ segundo $\left(\mathrm{VEF}_{1}\right)$, Teste de Caminhada de 6 minutos (TC6) e Teste de Escada (TE) se alteram proporcionalmente ao pulmão funcionante ressecado. Métodos: Foram incluídos pacientes candidatos a toracotomia para ressecção pulmonar. No pré-operatório (pré) e no mínimo três meses após a cirurgia (pós), realizaram espirometria, TC6 e TE. O TE foi realizado em escada com 12,16m de altura. O tempo para subir todos os degraus o mais rápido possível foi chamado tempo de escada (tTE). Os cálculos dos valores dos testes preditos para o pós-operatório (ppo) foram realizados conforme o número de segmentos funcionantes perdidos. Os valores pré, ppo e pós foram comparados entre si para cada teste. Estatística: foi utilizada a análise de variância para medidas repetidas (ANOVA), com significância de $5 \%$. Resultados: Foram estudados 40 pacientes. A ressecção pulmonar variou desde o ganho de dois segmentos funcionantes até a perda de 9 . Os valores pré, ppo e pós foram respectivamente: $\mathrm{VEF}_{1}$-pré $=2,6 \pm 0,8 \mathrm{~L}$, ppo $=2,3 \pm 0,8 \mathrm{~L}$, pós $=2,3 \pm 0,8 \mathrm{~L}\left(\mathrm{VEF}_{1}\right.$ pré $>\mathrm{VEF}_{1}$ ppo $=\mathrm{VEF}_{1}$ pós $)$, TC6-pré $=604 \pm 63 \mathrm{~m}$, ppo $=529 \pm 103 \mathrm{~m}$, pós $=599 \pm 74 \mathrm{~m}($ TC6pré $=$ TC6pós $>$ TC6ppo), tTE-pré $=32,9 \pm 7,6 \mathrm{~s}$, ppo $=37,8 \pm 12,1 \mathrm{~s}$, pós $=33,7 \pm 8,5 \mathrm{~s}$ (tTEpré $=$ tTEpós < tTEppo). Conclusão: Nas ressecções pulmonares, este grupo de pacientes perdeu função pulmonar medida através da espirometria, mas não perdeu a capacidade de exercício, medida através dos testes de escada e caminhada.

Descritores: Testes de Função Respiratória. Testes de Função Cardíaca. Espirometria.

${ }^{1}$ Research performed at Postgraduate Program on General Basis of Surgery, Botucatu School of Medicine, Sao Paulo State University (UNESP), Brazil. 


\section{Introduction}

Isolated thoracotomy is known to reduce pulmonary volumes and capacity for several weeks after surgery. In a resection of functioning lung tissue, such a reduction is permanent. Thus, surgery may be contraindicated when predicted postoperative (ppo) lung volumes are minimal and not compatible with life. According to some investigators, ppo values are lower than actual postoperative values ${ }^{1}$, this can carry surgery contraindications in patients that could tolerate the surgery. The results of exercise tests have been considered stronger prognostic predictors than spirometry, which only assesses lungs at resting and is, therefore, recommended for preoperative screening ${ }^{2}$. A very efficient test for the evaluation of exercise performance is ergospirometry. However, few are the centers where ergospirometers are available. Other tests, such as the stairclimbing test (SCT), the 6-minute walk test (6MWT) or the 12-minute walk test (12MWT), are not so efficient, but can be undertaken nearly everywhere.

SCT was described as predictive of surgical risk in 1961 by Souders et $a l .^{3}$, for whom the inability to climb two flights of stairs indicated high mortality risk. In 1987, SCT was demonstrated to be comparable to spirometry ${ }^{4}$. In the $1990 \mathrm{~s}$, a number of investigators reported its use to measure preoperative cardiopulmonary performance. Olsen et al. ${ }^{5}$ reported that patients unable to climb three flights of stairs had a high surgical risk. Holden et al. ${ }^{6}$, in turn, classified risk according to the number of steps climbed, while Pate et al..$^{7}$ established the height achieved without encouragement as the test parameter.

In 2007, Cataneo and Cataneo ${ }^{8}$ suggested the use of the parameter stair-climbing time ( $\mathrm{SCt}$ ), defined as the time taken to climb a stairway of known height with verbal encouragement. They demonstrated that, in comparison with $\mathrm{VO}_{2}$ max measured by ergospirometry, SCt had good accuracy. In the same year, Brunelli et al. ${ }^{9}$ associated the height achieved with postoperative morbidity and mortality. They demonstrated that patients climbing less than $12 \mathrm{~m}$ had higher rates of cardiopulmonary complications, and concluded that SCT is very good in stratifying surgical risk and should be used in all candidates for lung resection, as it is simple, inexpensive and effective, but large prospective studies need to be undertaken before stair climbing can be advocated in a standardized way. Cataneo et al. ${ }^{10}$ also showed that beyond $\mathrm{SCt}$, the 6MWT had good accuracy when compared with the $\mathrm{VO}_{2} \max$ of ergoespirometry and SCt and 6MWT combined showed nearly $100 \%$ sensitivity or specificity.

In this study, ppo FEV , was preoperatively calculated based on the amount of functioning parenchyma to be resected. In the literature, however, no means to calculate SCT and 6MWT ppo values are reported.

The main aim of this study was to assess whether FEV , $6 \mathrm{MWT}$ and SCT showed proportional loss of function following pulmonary resection.

\section{Methods}

After approval by the Research Ethics Committee of Botucatu Medical School-UNESP, all candidates for thoracotomy for pulmonary resection, who were older than 18 years of age, and hospitalized in the Thoracic Surgery Ward of Botucatu Medical
School Hospital, were invited to participate in this study. Exclusion criteria included severe arterial hypertension (systolic arterial pressure $>200 \mathrm{mmHg}$ and diastolic arterial pressure $>$ $110 \mathrm{mmHg}$ ), decompensated heart failure, infarction within the past 90 days instable angina, decompensated COPD, electrocardiogram showing complete left bundle branch block, walking difficulty (orthopedic, neurological, vascular abnormalities), inability to undergo the walk test and any acute condition.

Spirometry was followed by $6 \mathrm{MWT}$ and SCT. An obligatory rest period of 20 minutes was observed between $6 \mathrm{MWT}$ and SCT. Because inability to complete the walk test was an exclusion criterion, 6MWT was performed before SCT.

Data collected before and after exercise testing included: arterial blood pressure, respiratory rate, heart rate (HR) and oxygen saturation $\left(\mathrm{O}_{2}\right.$ Sat $)$. $\mathrm{HR}$ and $\mathrm{O}_{2}$ Sat were monitored throughout testing. $\mathrm{O}_{2}$ Sat was measured with a portable digital pulse oxymeter (Nonin Onyx 9500-Fingerpulsoximeter) ${ }^{\circledR}$.

All three tests (spirometry, SCT and 6MWT) were repeated at least 3 months after surgery, when pulmonary volumes and capacity were expected to be no longer reduced as a result of thoracotomy.

Spirometry was performed according to the American Thoracic Society guidelines (ATS). A Med-Graphics Pulmonary Function System 1070 was used with the patient in the sitting position. Forced vital capacity was measured at least three times choosing the curve with the highest $\mathrm{FEV}_{1}$.

The 6-minute walk test, which was also performed according to ATS guidelines, consisted of measuring the distance covered by the patient in meters after six minutes of encouraged walking in the shade along a flat 120 -m corridor.

SCT was based on our previous study ${ }^{8,10}$. It was performed in the shade, on a staircase of $30^{\circ}$ in incline which consisted of six flights, each flight having twelve steps (72 steps in total) measuring $16.9 \mathrm{~cm}$. Total ascent height was $12.16 \mathrm{~m}$. Patients were asked to climb all the steps in the shortest possible time with verbal encouragement between flights. Testing was stopped only for fatigue, limiting dyspnea, thoracic pain, or exhaustion. The time taken to climb the stairs ( $\mathrm{SCt}$ ) was expressed in seconds.

Functioning and non-functioning pulmonary segment: a pulmonary segment was considered non-functioning when atelectasis, fibroatelectasis, tumor or peri-tumor radiopacity were radiologically detected; and bronchial obstruction $>75 \%$ at bronchoscopy. Half of the segment was considered functional if obstructions ranged from 50 to $75 \%$, whereas the entire segment was considered as functional when obstructions were $<50 \%$ and peripheral radiological abnormalities were absent. The total number of functioning segments (FS) was assumed to be 19 (10 in the right lung and 9 in the left lung).

Calculation of ppo values: the predicted postoperative values (ppoV) for $\mathrm{FEV}_{1}$ and the distance walked in the 6MWT were calculated by rule of three direct using the values obtained preoperatively (pre V) as follows: ppoV $=$ preV x (FS - resected FS) $\div$ FS. Predicted postoperative stair-climbing time (ppoSCt) was estimated by rule of three inverse as follows: ppoSCt $=$ preSCt $\mathrm{x}$ FS $\div$ (FS - resected FS), where preSCt is preoperative stairclimbing time.

Statistical analysis: pre and postoperative results were analyzed using descriptive statistics. Spirometric, 6MWT and SCT data were compared using parametric statistics. Preoperative, 
postoperative and ppo $\mathrm{FEV}_{1}, 6 \mathrm{MWT}$ distance and SCt were compared by parametric repetead-measures ANOVA with significance level set at 5\%.

Statistical analysis was conducted for all patients in one group and also for patients separated as 2 groups (loss of $<4$ functioning segments and loss of $\geq 4$ functioning segments).

Correlations between ppo and postoperative values for each variable were tested estimating r-values and linear regressions.

\section{Results}

A total of 40 patients were assessed before and after surgery. Patient age ranged from 18 to 70 years $($ mean $\pm \mathrm{SD}=$ $48 \pm 16$ ). Twenty-two were male, 35 had lung cancer and 5 had lung infectious sequelae. FEV $\mathrm{F}_{1}$ mean $\pm \mathrm{SD}$ was $84.0 \pm 25.3 \%$. Both pre-and postoperatively, three patients showed desaturation
$>4 \%$ during exercise testing, though no clinical repercussions were deemed extreme enough to terminate the test.

Number of functioning segments after surgery: in only one case, two segments were gained due to bronchial patency by sleeve resection. In eight cases, there was no segment loss as all segments resected were already non-functioning before resection. The number of segments lost was one in 11 cases, two in five cases, three in one case, four in three cases, five in nine cases, seven in one case, and nine in one case.

$\mathrm{FEV}_{1}$ postoperative was smaller than $\mathrm{FEV}_{1}$ preoperative, but $6 \mathrm{MWT}$ postoperative and SCt postoperative were similar to 6MWT preoperative and SCt preoperative. $\mathrm{FEV}_{1}, 6 \mathrm{MWT}$ distance and SCt preoperative (pre), predicted postoperative (ppo), and postoperative (pos) values expressed as mean and standard deviation, as well as p-values and test interpretation for all patients in one group are shown in Table 1.

TABLE 1 - Variables FEV in liters, 6MWT distance in meters, and SCt in seconds. Mean and standard deviation for preoperative (pre), predicted postoperative (ppo) and actual postoperative (pos), $\mathrm{p}$-values and interpretation including all patients

\begin{tabular}{lccccl}
\hline Variable & pre & ppo & pos & p & Interpretation \\
\hline FEV $_{1}$ & $2.6 \pm 0.8(\mathrm{a})$ & $2.3 \pm 0.8(\mathrm{~b})$ & $2.3 \pm 0.8(\mathrm{~b})$ & $<0.001$ & Pre $>$ ppo $=$ pos \\
6MWT & $604 \pm 63(\mathrm{a})$ & $529 \pm 103(\mathrm{~b})$ & $599 \pm 74(\mathrm{a})$ & $<0.001$ & Pre $=$ pos $>$ ppo \\
SCt & $32.9 \pm 7.6(\mathrm{~b})$ & $37.8 \pm 12.1(\mathrm{a})$ & $33.7 \pm 8.5(\mathrm{~b})$ & $<0.001$ & Pre $=$ pos $<$ ppo \\
\hline
\end{tabular}

The analysis of the patients separated into two groups revealed no statistical difference in pre, ppo and pos $\mathrm{FEV}_{1}, 6 \mathrm{MWT}$ distance and $\mathrm{SCt}$ when the number of resected segments was less than four. However, when four or more segments were resected, the statistical interpretation was the same as that for all patients in one group.
The correlations between ppo and actual pos $\mathrm{FEV}_{1}$, 6MWT distance and SCt are depicted in Figures 1, 2 and 3, respectively. The best correlation was between ppo $\mathrm{FEV}_{1}$ and pos $\mathrm{FEV}_{1}$, and the worst correlation was between ppo $6 \mathrm{MWT}$ and pos 6MWT.

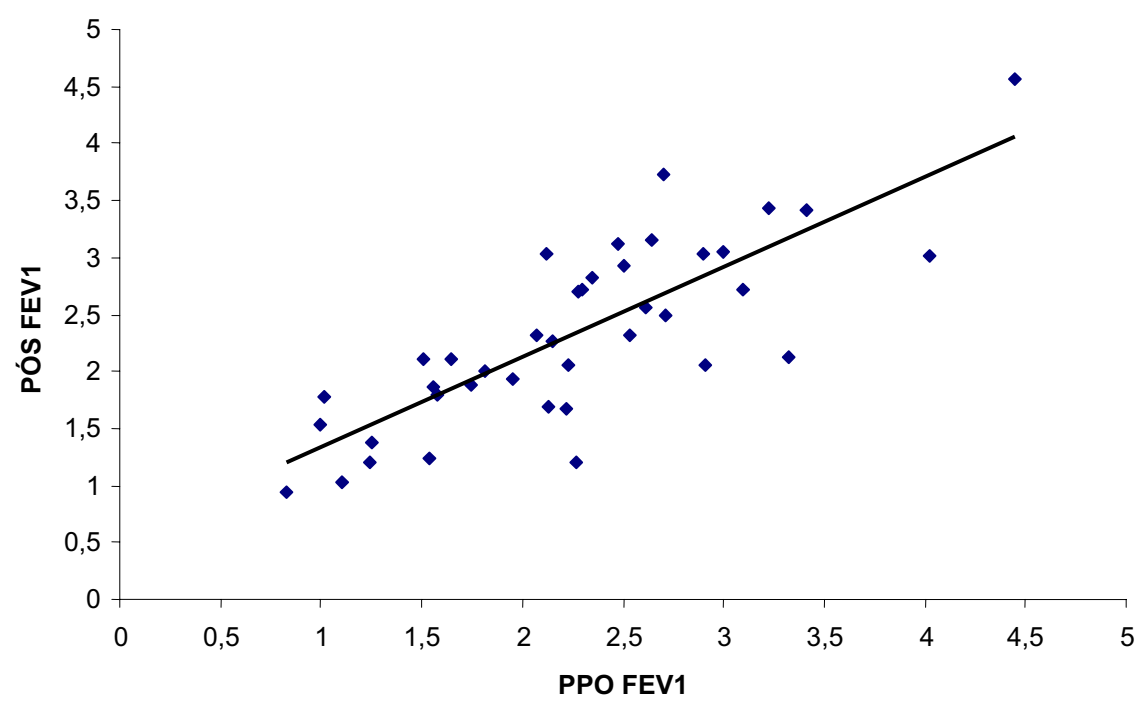

FIGURE 1 - Correlation between ppoFEV and posFEV $. r=0.8021(\mathrm{p}<0.001)$. Linear regression: $\operatorname{posFEV}_{1}=0.539+0.790 \mathrm{xpoFEV}_{1}$ 


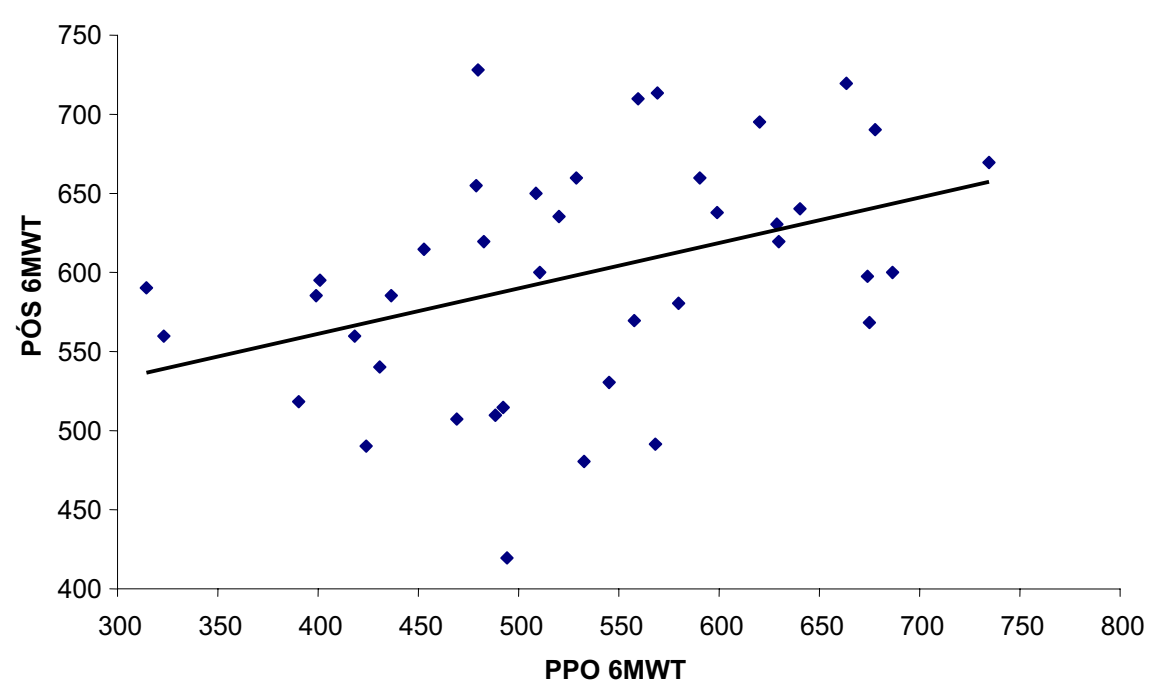

FIGURE 2 - Linear correlation between ppo6MWT and pos6MWT. $r=0.3977(\mathrm{p}<0.01)$. Linear regression: pos6MWT $=447.17+0.29$ ppo $6 \mathrm{MWT}$

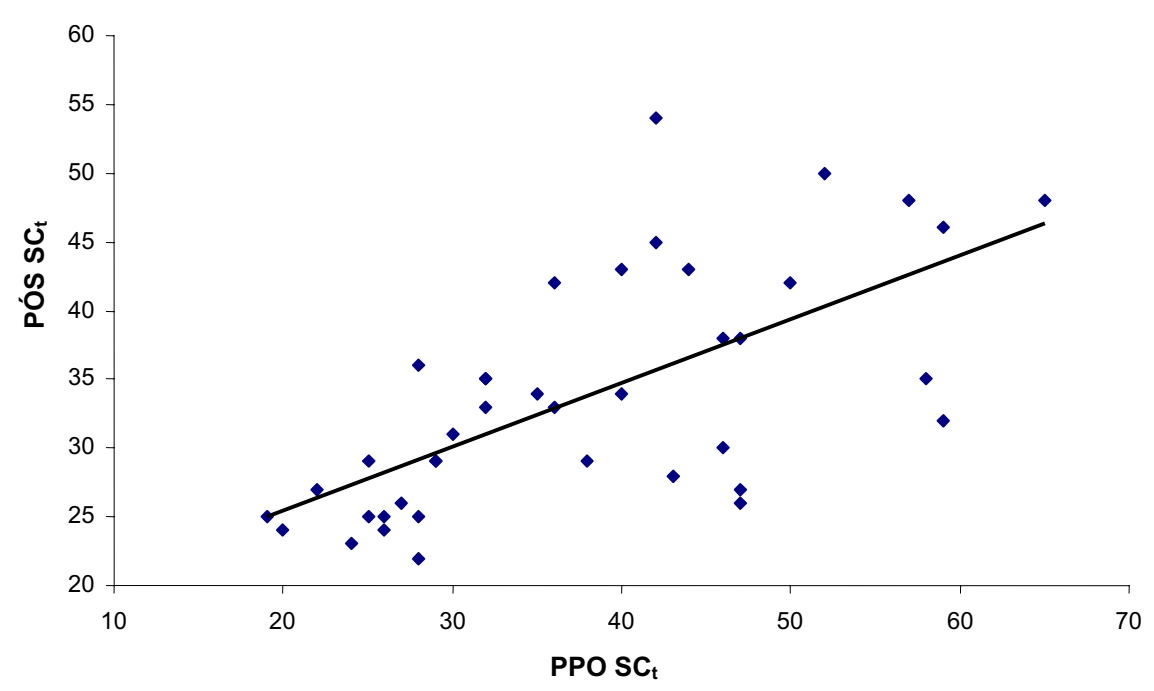

FIGURE 3 - Linear correlation between ppoSCt and posSCt. $r=0.6618(p<0.001)$. Linear regression: $\operatorname{pos} \mathrm{SCt}=16.14+0.46$ ppoSCt.

\section{Discussion}

Of the three parameters assessed in this study, FEV showed the best linear correlation between predicted and actual postoperative values. No significant differences were observed between ppo and postoperative $\mathrm{FEV}_{1}$. Thus, considering exclusively the functioning pulmonary segments as lost when calculating ppo $\mathrm{FEV}_{1}$, seems to be acceptable. To date, the majority of studies available do not make it clear whether only functioning segments are considered as lost when ppo function is calculated. When functioning and non-functioning segments removed are taken into account, the predicted postoperative value is likely to be smaller than the actual postoperative value. Zeiher et al. ${ }^{1}$, in a retrospective study, demonstrated that ppoFEV underestimates the actual postoperative $\mathrm{FEV}_{1}$ by $250 \mathrm{ml}$ in patients undergoing lobectomy, and proposed adding $250 \mathrm{ml}$ to the calculated ppo value. These findings were probably caused by the non-separation of functioning from non-functioning resected segments. Counting an occluded segment as a functioning segment removed does yield a lower ppo value, but, rather than underestimation, this is a case of miscalculation. In the case of exercise tests, however, the rather weak correlations found indicate that postoperative performance depends on factors other than pulmonary volumes. The fact that the actual postoperative values for 6MWT and SCT variables were higher than those predicted favors those patients who are taken to surgery with minimum ppo values.

Scintillography can increase the sensitivity of the method as calculation using simple arithmetic mean assumes that each 
segment represents $1 / 19$ of the lung function. This would be close to be correct if scintillographic uptake were the same for each segment. However, if uptake is greater on one side than on the other, the functioning segment removed from the side with greater uptake would be more functional than the segment on the side with lower uptake. In this case, the weighted mean should be used for calculation. In this study, there was no case requiring scintillography, so all functioning segments were considered to equally contribute for pulmonary function.

Even though the risk of complications after pulmonary resection has already been demonstrated to be higher as ppoFEV decreases $^{11}$, other studies have not yielded the same results ${ }^{12}$. FEV ${ }_{1}$, as well as other spirometric values are assessed in lungs at resting, not taking into account the physical stress caused by surgery or the physical effort required by daily activities. This indicates that spirometry alone is not adequate to predict surgical risk. The literature has lately shown that the maximum oxygen uptake measured during exercising by ergospirometry is the ideal predictor of surgical risk ${ }^{12}$. Nonetheless, few are the centers where an ergospirometer is available. Given that stair-climbing and walk tests have already proven to be good predictors of surgical risk $^{6,9,10,13}$, and that stair-climbing time accuracy is good as compared with $\mathrm{VO}_{2}$ max measured by ergospirometry ${ }^{8,10}$, the use of these tests, which are low-cost and readily available in all centers, deserve consideration.

The 6-minute walk test can be easily performed because of the familiarity of the patients with this form of exercise. Indeed, it can be used with most patients, including the elderly with lower levels of understanding that are unable to undergo treadmill or cycloergometric testing.

In a systematic review of walk tests ${ }^{14}$, it was observed that the 6MWT was most commonly employed in patients with COPD or heart failure, and less frequently in cases of surgery. In these studies, the distance walked strongly correlated with $\mathrm{VO}_{2}$ max measured on a cycle ergometer or treadmill. Some investigators have shown that when the distance walked was $300 \mathrm{~m}$ or less, the risk of mortality or hospitalization was likely to increase.

Stair-climbing test performance has been diversely assessed. Results have been reported in several ways, from height reached in numbers of flights climbed without encouragement ${ }^{3-6}$, to the number of steps climbed with encouragement to climb the fastest possible $8,10,15$. These differences in method have made it difficult to compare the results obtained across different centers. Nonetheless, regardless of the approach used, this test has been very helpful.

Brunelli et al. ${ }^{13}$ showed that stair climbing was the best predictor of mortality or severe cardiopulmonary complications after lung resection. However, they clearly stated that patients should climb at a pace of their own choice with no concern about speed $^{9,13}$. Koegelenberg et al. ${ }^{15}$ and Cataneo et al. ${ }^{8,10}$, in turn, focused on the speed of ascent. They used a stairway of known height with stair-climbing time as the variable, whereas Brunelli et al. ${ }^{9,13}$ focused on the height achieved. Anyway, both approaches were found to be valid. However, when patients are allowed to climb at their own pace without encouragement, very high staircases are needed because exhaustion is height-limited. On the other hand, when the focus is on time and patients are encouraged to climb as rapid as possible, lower stairways can be used because, in this case, exhaustion is speed-limited.
In our center, there are few stair flights, but the measurement of time makes it possible to compare our results with those obtained in any other study also using time as a variable. Time correlates with the constant height achieved, allowing the calculation of average speed. An analogy might be established between SCT and 6MWT: while the first focuses on a fixed height to assess time, the latter focuses on a fixed time to measure distance.

In this study, FEV ${ }_{1}$ could be roughly calculated on the basis of the number of functioning segments lost. However, stratifying the patients into 2 groups according to the number of functioning segments removed revealed that $\mathrm{FEV}_{1}$ calculation was more precise when the number of segments was 4 or more. Similarly, other investigators have reported a strong correlation between predicted and actual postoperative values when more than 3 segments were resected, and no correlation when resections were smaller ${ }^{16}$, but they did not make it clear whether functioning segments alone were considered as lost. Among our patients, no significant difference between ppo and postoperative values was found after small resections, even when only resected functioning segments were taken into account. Perhaps, differences were so slight that significance would not be reached unless a much larger number of patients were assessed, but the calculation of such small losses did not reveal any significant difference between preoperative and ppo values either. This probably occurred because, in many cases, the segments resected were already not functioning before surgery and, therefore, could not be considered as lost. Even more sophisticated calculation methods using ventilation and perfusion scintillography have not been able to adequately predict ppoFEV ${ }_{1}^{17}$.

Several permanent or transient reasons could hinder the adequate prediction of lung volumes by spirometry after pulmonary resection. Ventilation disorders induced by secretion, atelectasis, edema, infection or even physiological alveolar collapse can alter lung function.

The fact that preoperative exercise testing parameters remained similar to those measured after resection shows that, in spite of $\mathrm{FEV}_{1}$ loss, our patients kept their exercise capacity, being able to perform the less stressing 6MWT as well as the more vigorous SCT.

Similar findings have been reported by others who observed that, although $\mathrm{FEV}_{1}$ and $\mathrm{VO}_{2}$ max values decreased after pulmonary resection, the correlation between $\mathrm{FEV}_{1}$ fall and $\mathrm{VO}_{2}$ max fall was weak. Thus, they concluded that fall in FEV, was a poor predictor of the fall in exercise capacity after lung resection, and that lobectomy had little or no effect on $\mathrm{VO}_{2} \max ^{18}$. Notwithstanding, recent studies have stressed the importance of exercise testing even for the prediction of hospital costs ${ }^{13,19}$. These investigators showed that reduced exercise capacity is associated with longer hospital stays and costs among patients undergoing pulmonary resection.

It is probable that the postoperative exercise test results reported here remained at preoperative levels because the performance of our patients was well within the acceptable range, in contrast with the patients studied by Brunelli et al. ${ }^{13}$, who were not able to climb $12 \mathrm{~m}$ at their own pace, and thus generated a 2.5fold increase in hospital costs as compared with those who climbed $22 \mathrm{~m}$. Indeed, patients with no cardiopulmonary reserve require better preoperative support. 


\section{Conclusion}

This study demonstrated that, anatomical calculations could accurately predict postoperative $\mathrm{FEV}_{1}$ values, but overestimated the loss of exercise capacity as measured by stair-climbing test and 6 minute walk test.

\section{References}

1. Zeiher BG, Gross TJ, Kerny JA, Lanza LA, Peterson MW. Predicting postoperative pulmonary function in patients undergoing lung resection. Chest. 1995; 108:68-72.

2. Ferraza AM, Martolini D, Valli G, Palange P. Cardiopulmonary exercise testing in the functional and prognostic evaluation of patients with pulmonary diseases. Respiration. 2009;77:3-17.

3. Souders CR. Clinical evaluation of the patient for thoracic surgery. Surg Clin North Am. 1961;41:545-56.

4. Bolton JWR, Weiman DS, Haynes JL, Hornung CA, Olsen GN, Almond CH. Stair climbing as an indicator of pulmonary function. Chest. 1987;92:783-8.

5. Olsen GN, Bolton JWR, Weiman DS, Hornung CA. Stair climbing as an exercise test to predict the postoperative complications of lung resection: two years' experience. Chest. 1991;99:587-90.

6. Holden DA, Rice TW, Stelmach K, Meeker DP. Exercise testing, 6 minute walk, and stair climb in the evaluation of patients at high risk for pulmonary resection. Chest. 1992;102:1774-9.

7. Pate P, Tenholder MF, Griffin JP, Eastridge CE, Weiman DS. Preoperative assessment of the high-risk patient for lung resection. Ann Thorac Surg. 1996;61:1494-500.

8. Cataneo DC, Cataneo AJ. Accuracy of the stair climbing test using maximal oxygen uptake as the gold standard. J Bras Pneumol. 2007;33(2):128-33. Available from URL: http:// www.jornaldepneumologia.com.br/english/artigo_detalhes.asp?id=406 9. Brunelli A, Socci L, Refai M, Salati M, Xiumé F, Sabbatini A. Quality of life before and after major lung resection for lung cancer: a prospective follow-up analysis. Ann Thorac Surg. 2007;84:410-6.
10. Cataneo DC, Kobayasi S, Carvalho LR, Paccanaro RC, Cataneo AJM. Accuracy of six minute walk test, stair test and spirometry using maximal oxygen uptake as gold standard. Acta Cir Bras. [serial on the Internet] 2010 Mar-Apr;25(2). Available from URL: http://www.scielo.br/acb 11. Kearney DJ, Lee TH, Reilly JJ, DeCamp MM, Sugarbaker DJ. Assessment of operative risk in patients undergoing lung resection: importance of predicted pulmonary function. Chest. 1994;105:75-9.

12. Win T, Jackson A, Sharples L, Groves AM, Wells FC, Ritchie AJ, Laroche CM. Cardiopulmonary exercise tests and lung cancer surgical outcome. Chest. 2005;127:1159-65.

13. Brunelli A, Refai M, Xiumé F, Salati M, Sciarra V, Socci L, Sabbatini A. Performance at symptom-limited stair-climbing test is associated with increased cardiopulmonary complications, mortality, and costs after major lung resection. Ann Thorac Surg. 2008;86:240-8.

14. Solway S, Brooks D, Lacasse Y, Thomas S. A qualitative systematic overview of the measurement properties of functional walk tests used in the cardiorespiratory domain. Chest. 2001;119:256-70.

15. Koegelenberg CFN, Diacon AH, Irani S, Bolliger CT. Stair climbing in the functional assessment of lung resection candidates. Respiration. 2008;75:374-9.

16. Ali MK, Mountain CF, Ewer MS, Johnston D, Haynie TP. Predicting loss of pulmonary function after pulmonary resection for bronchogenic carcinoma. Chest. 1980;77(3):337-42.

17. Ladurie ML, Ranson-Bitker B. Uncertainties in the expected value for forced expiratory volume in one second after surgery. Chest. 1986;90:222-8.

18. Pelletier C, Lapointe L, Leblanc P. Effects of lung resection on pulmonary function and exercise capacity. Thorax. 1990;45:497-502.

19. Weinstein H, Bates AT, Spaltro BE, Thaler HT, Steingart RM. Influence of preoperative exercise capacity on length of stay after thoracic cancer surgery. Ann Thorac Surg. 2007;84:197-202.

\section{Acknowledgment}

We thank the Research Support Group of the Botucatu School of Medicine, UNESP for language revision.

Conflict of interest: none Financial source: none

\section{Correspondence:}

Antonio José Maria Cataneo

Disciplina de Cirurgia Torácica-Departamento de Cirurgia e Ortopedia

Faculdade de Medicina de Botucatú-UNESP

18.618-970 Botucatú-SP Brasil

Phone: (55 14)3811-6230

Fax: (55 14)3815-7615

acataneo@,fmb.unesp.br

Received: March 23, 2010

Review: May 20, 2010

Accepted: June 24, 2010

\section{How to cite this article}

Pancieri MVC, Cataneo DC, Montovani JC, Cataneo AJM. Comparison between actual and predicted postoperative stair-climbing test, walk test and spirometric values in patients undergoing lung resection. Acta Cir Bras. [serial on the Internet] 2010 Nov-Dec;25(6). Available from URL: http://www.scielo.br/acb 